\title{
PENGARUH KOMUNIKASI ORGANISASI TERHADAP EFEKTIVITAS KERJA APARAT DI KANTOR KELURAHAN ARATENG KECAMATAN TELLU LIMPOE KABUPATEN SIDENRENG RAPPANG
}

\author{
1) Suraswati, ${ }^{2)}$ Kamaruddin Sellang, ${ }^{3)}$ Monalisa Ibrahim \\ Fakultas IImu Sosial dan IImu Politik Universitas Muhammadiyah Sidenreng Rappang \\ uraswati43162056.1b@gmail.com \\ kamaruddinsellang@yahoo.co.id \\ monalisa2231@yahoo.com
}

\begin{abstract}
Abstrak
Penelitian ini bertujuan untuk mengetahui pengaruh Komunikasi Organisasi Terhadap Efektivitas Kerja Aparat Di Kantor Kelurahan Arateng Kabupaten Sidenreng Rappang. Populasi penelitian ini adalah 2.133 orang dan sampel sebanyak 32 orang. Teknik penarikan sampel yang digunakan yaitu sampel jenuh. Tipe penelitian ini adalah deskriptif kuantitatif. Teknik pengumpulan data adalah observasi, wawancara, penelitian pustaka dan kuesioner. Teknik analisis data menggunakan analisis deskriptif, uji kualitas data (validitas dan reabilitas), uji asumsi klasik, regresi linear dan pengujian hipotesis. Hasil penelitian menunjukkan bahwa komunikasi organisasi $62.68 \%$ berkategori berpengaruh meliputi bijaksana dan kesopanan $61.8 \%$, penerimaan umpan balik $63 \%$, berbagi informasi $60 \%$, memberikan informasi tugas $66.8 \%$. mengurangi ketidakpastian tugas $61.8 \%$.efektivitas kerja $61.4 \%$ berkategori berpengaruh meliputi kuantitas kerja $61.8 \%$, kualitas kerja $62.4 \%$, pemanfaatan waktu $60 . \%$. Faktor-faktor yang mempengaruhi komunikasi organisasi $58.26 \%$ berkategori cukup berpengaruh meliputi komunikasi horizontal $62.4 \%$, komunikasi diagonal $56.2 \%$, komunikasi vertikal $56.2 \%$. Hal ini menunjukkan pengaruh Komunikasi Organisasi Terhadap Efektivitas Kerja Aparat Di Kantor Kelurahan Arateng Kabupaten Sidenreng Rappang adalah $61 \%$ dari $100 \%$ hasil yang diharapkan, dimana ini tergolong dalam kategori "berpengaruh".
\end{abstract}

Kata kunci : komunikasi organisasi dan efektivitas kerja aparat

\begin{abstract}
This study aims to determine the effect of Organizational Communication on the Work Effectiveness of Apparatus in the Arateng Village Office, Sidenreng Rappang District. The population of this study was 2,133 people and a sample of 32 people. The sampling technique used is saturated samples. This type of research is quantitative descriptive. Data collection techniques are observation, interviews, library research and questionnaires. Data analysis techniques using descriptive analysis, data quality tests (validity and reliability), classic assumption tests, linear regression and hypothesis testing.The results showed that organizational communication $62.68 \%$ influential categories include wise and politeness $61.8 \%$, feedback acceptance $63 \%$, information sharing $60 \%$, giving information assignments $66.8 \%$. reduce task uncertainty $61.8 \%$. work effectiveness $61.4 \%$ influential categories include the quantity of work $61.8 \%$, work quality $62.4 \%$, time utilization $60 . \%$. The factors that influence organizational communication $58.26 \%$ are quite influential include horizontal communication $62.4 \%$, diagonal communication $56.2 \%$, vertical communication $56.2 \%$. This shows the effect of Organizational Communication on the Effectiveness of Workers in the Arateng Village Office Sidenreng Rappang District is $61 \%$ of the $100 \%$ expected results, which is classified in the category of "influence".
\end{abstract}

Keywords: organizational communication and apparatus work effectiveness 


\section{A. PENDAHULUAN}

Kinerja adalah indikator yang sangat diperlukan dalam mengukur suatu tingkat pengcapaian pelaksanaan suatu program kegiatan yang melalui target sasaran, visi, misi beserta tujuan terhadap organisasi tersebut. Kinerja merupakan suatu hasil dari seluruh aparat yang dapat diukur, baik diukur menggunakan angka atau menggunakan sebuah ekspresi yang memungkinkan terjadinya komunikasi. Kinerja juga merupakan suatu pencapaian dari tujuan organisasi, adapun pencapaian yang dihasilkan berbentuk seperti output kuantitatif dengan kualitatif, kreatifitas, fleksibilitas, yang dapat dimanfaatkan atau hal- hal yang sudah di tetapkan dalam organisasi( Suprihati, 2014).

Moeheriono dalam Zainuddin (2017:383) mengatakan bahwa kinerja merupakan suatu hasil dalam proses kerja yang akan dicapai oleh individu terhadap organisasi tersebut, baik itu secara kuantitatif dengan kualitatif berdasarkan dengan kewenangan serta tanggungjawab masing-masing, dalam hal mencapai hasil terhadap organisasi secara legal dan tidak melampaui batas hukum yang ada. Secara umum kinerja bisa dikatakan sebagai suatu hubungan dengan prestasi kerja secara nyata dengan tanggapan yang sewajarnya. Kinerja juga merupakan sebuah implementasi dan sesuatu yang telah direncanakan dan disusun terhadap organisasi Tersebut. Implementasi tersebut dilaksanakan oleh sumber daya manusia yang sudah memiliki sesuatu yang sangat penting terhadap suatu organiasi seperti kemampuan, kompetensi, motivasi dan kepentingan. Kinerja adalah sebuah hasil yang sudah diharapkan pada semua orang berdasarkan ukuran yang sudah berlaku untuk pekerjaan yang berkaitan.

Undang-undang No 5 tahun 2014 tentang Aparatur Sipil Negara (ASN) pasal 4 huruf $\mathrm{j}$ berbunyi memberikan sebuah layanan untuk publik secara jujur, tanggap, cepat, tepat, dan akurat. ASN diharapkan memilki jiwa pegabdian dalam pelayanan kepada masyarakat. Istilah lain dari kinerja sering digunakan untuk mengungkapkan sebuah prestasi dan suatu peningkatan dalam sebuah keberhasilan dalam individu dan kelompok individu, kinerja juga bisa ditemukan jika individu dan kelompok invidu
p-ISSN 2302-6960

e-ISSN 2716-165X

mempunyai kriteria dalam suatu keberhasilan yang sudah disepakati sebelumnya.

Setiap kelompok organisasi

menetapkan tugas kepada masing-masing anggotanya agar tugas-tugas itu lanjutkan dan dilaksanakan sesuai fungsi pegawai. Kemudian fungsi itu dapat dilakukan dengan tepat maka diperlukan pelaksanaan sebuah komunikasi yang baik sehingga itu menimbulkan kerjasama dan lebih kompak antar pegawai pada akhirnya mengakibatkan pada peningkatan efektivitas kerja demi tercapainya suatu target yang sudah di tetapkan sebelumnya. Peningkatan efektiktivitas kerja tersebut dapat juga dilihat dari suatu kemampuan pada instansi dalam mencapaihasil pada program kerja yang sudah disepakati sebelumnya.Hal ini menimbulkan dampak pada perlunya kesadaran dari setiap pegawai untuk meningkatkan kerjasama yang baik sesama anggotanya melalui pembinaan komunikasi yang baik sebab tidak dapat dipungkiri bahwa jauh lebih baik pula peningkatan efektivitas kerja pegawai. Dimana peningkatan keefektifan kerja yang sangat tinggi merupakan kunci utama dalam mengembangkan instansi. Begitun pada pegawai Kantor Kelurahan Arateng dalam menjalankan tugas dan kewenangannya kepada rakyat dengan baik harus meningkatkan kerja sama melalui penciptaan komunikasi yang diketahui efektif diantara semua unit-unit kerja.

Penyelenggaraaan komunikasi yang baik secara langsung akan mengakibatkan terhadap suatu peningkatan keefektifan kerja aparat yang baik pula. Keefesienan kerja aparat pada Kantor Kelurahan Arateng masih sangat dieperlukan namanya peningkatan. Peningkatan dalam efektivitas kerja ini dapat diketahui sebagai salah satu yang dibangun melalui potensi manusia dengan melakukan komunikasi yang sangat baik. Kelurahan Arateng adalah suatu kantor yang ada di Kabupaten Sidenreng Rappang, Fenomena yang berlangsung di Kantor Kelurahan Arateng sehubungan dengan komunikasi organisasi meliputi yaitu terjadi karena kurangnya miskomunikasi atau missunderstanding (kesalahan persepsi) sehingga hasil kerjasama dan komunikasi antara tim kurang baik, maka ini menunjukkan suatu masalah terbesar terhadap suatu organisasi disebabkan oleh 
salah pengertian dan kekurangan informasi untuk itu diperlukan adanya kerjasama.

Hasil penelitian terdahulu yang sudah dilaksanakan oleh Dewi Sartika 2014 dengan judul Pengaruh Komunikasi Organisasi Terhadap Efektivitas Kerja Pegawai Pada Sekertariat Daerah Kabupaten Pinrang bahawa setiap lembaga pemerintah membutuhkan potensi manusia atau pegawai yang berkompeten dan berkualitas serta memiliki dedikasi yang tinggi dalam pelaksanaan dan pengembangan tugas beserta tanggung jawabnya dengan baik, sebab pegawai adalah suatu unsur yang sangat dibutuhkan dalam memperoleh suatu keberhasilan dalam organisasi. Utamanya dalam sebuah instansi pemerintah harus tercermin suatu sosok aparatur negara yang memilki sifat jujur, adil, disiplin, profesional dan sadar akan tanggungjawabnya sebagai pelayanan publik untuk melahirkan suatu lembaga pemerintahan yang sangat baik seperti yang diingankannya. Dengan mutu dan kompetensi yang dimilki oleh setiap pegawai maka setiap kegiatan yang dilaksanakan dalam instansi tersebut dapat berjalan secara sempurna sehingga dapat memperoleh suatu sasaran yang diharapkan secara maksimal.

Kompetensi yang dimiliki oleh seluruh personil pegawai dalam instansi yaitu memilki kemampuan dalam berkomunikasi secara efektif seperti internal maupun eksternal, karena sebelumnya sudah diketahui bahwa dalam sebuah instansi terbagi dari beberapa orang dengan memilki latar belakang dan kebutuhan yang berbeda rupanya ini menunjukkan bentuk suatu keutuhan untuk menggerakkan dalam mencapai Sebuah sasaran yang telah sudah disepakati. Penyatuan persepsi ini menunjukkan sebuah tujuan membutuhkan adanya hubungan kerjasama yang baik sesama atasan dan bawahan. kerjasama ini bisa terselenggara dengan sempurna jika adanya dukungan oleh pelaksanaan komunikasi yang baik pula karena komunikasi yaitu suatu alat untuk memupuk dan saling pengertian dalam setiap individu sehingga menumbuhkan suatu kondisi kerja yang menyenangkan dimana terwujudnya kerjasama, saling mengerti,menghormati, dan mengakui sebuah eksistensi bagi setiap anggotanya dalam organisasi sehingga terlaksana dengan baik seperti pegawai dapat menyampaikan suatu pendapat yang e-ISSN 2716-165X diinginkan oleh bawahan maupun pimpinannya. Dengan demikian, jelaslah bahwa sebuah komunikasi organisasi merupakan kebiasaan untuk merangkai sebuah hubungan antar individu dan kelompok.

Setiap organisasi memberikan tugas kepada masing-masing anggotanya agar tugas-tugas itu itu kemudian dilaksanakan ke dalam fungsi pegawai. Selanjutnya fungsi tersebut dapat dilakukan secara tepat maka diperlukan pelaksanaan bagi komunikasi yang sudah dikatakan efektif sehingga dapat menumbuhkan kerjasama yang kompak antar pegawai yang akhirnya akan menimbulkan dalam peningkatkan efektivitas kerja demi memperoleh sebuah target yang telah diinginkan sebelumnya.Seperti yang dikatakan sebelumnya bahwa penyelenggaraan komunikasi yang baik secara langsung akan menimbulkan pengaruh terhadap peningkatan keefektifan kerja aparat yang baik pula.

Hasil observasi yang dilakukan pada bulan November tahun 2019 yang peneliti laksamakan di Kantor Kelurahan Arateng masih memperlihatkan keefektifan kinerja pegawai yang rendah, maka dapat dibuktikan berdasarkan indikator-indikator seperti :

1. Hasil dari setiap pekerjaan yang sudah dicapai oleh aparat Kantor Kelurahan belum optimal, conthnya : Dalam pembuatan keterangan KK (Kartu Keluarga) harus selesai sebanyak 7 buah kartu keluaraga dalam 2 hari, tapi kenyataanya dalam 2 hari baru terselesaikan empat(4) buah kartu keluarga.

2. Penyelesaian kerja tidak tepat waktu, contohnya : penyerahan KTP ( Kartu Tanda Penduduk) diberikan tidak tepat waktu seperti dengan yang diinginkan si pembuat/pemohon.

Keefektifan kerja aparat yang masih kurang pada Kantor Kelurahan Arateng sesuai yang diuraikan diatas, salah satunya diduga disebabkan oleh :

1. Kurangnya penguasaaan tbagi hal yang bersifat teknis yang ditetapkan pada kegiatan operasional (Komputerisasi). Contohnya : aparat ditugaskan dalam pengetikan seperti surat keterangan kartu keluarga dengan cermat dan teliti dalam melaksanakan pekerjaanya, dikarnakan data-data administrati pemohon kartu 
keluarga yang belum terselesaikan maka terjadi kekeliruan dalam pengetikan.

2. Kurangnya dorongan kerja yang sering bermunculan dalam diri aparat yang berdampak pada pekerjaan tersebut . Contohnya : berdasarkan hasil observasi masih adanya aparat Kantor Kelurahan Arateng yang terlambat bahkan tidak masuk kerja pada masajam kerja.

3. Kurangnya komunikasi terhadap atasan dan staf. Contohnya : terjadinya mis komunikasi sehingga aparat masih sulit memahami dan kurang merespon terhadap tugas yang telah diberikan sehingga menimbulkan hasil kerjasama dan respon serta komunikasi anatara aparat dan pimpinan kurang baik.

Komunikasi organisasi cukup berhubungan erat bagi keefektifan kerja aparat jika komunikasi organisasi berlangsung dengan sangat baik maka terjadi efektivitas kerja aparat. Suatu komunikasi dibutuhkan juga dalam organisasi dimana dengan adanya komunikasi organisasi yang efektif dapat tercipta suatu efektivitas kerja dalam lingkungan suatu organisasi . Dari temuan dan analisis tersebut maka calon peneliti menarik kesimpulan untuk melaksanakan penelitian dengan judul Pengaruh Komunikasi Organisasi terhadap Efektivitas Kerja Pegawai di Kantor Kelurahan Arateng Kecamatan Tellu Limpoe Kabupaten Sidenreng Rappang dengan tujuan untuk memahami pengaruh komunikasi organisasi terhadap efektivitas kerja aparat di Kantor Kelurahan Arateng Kecamatan Tellu Limpoe dan untuk mengetahui faktor-faktor komunikasi organisasi tehadap efektivitas kerja aparat di Kantor Kelurahan Arateng Kecamatan Tellu Limpoe

\section{Konsep Administrasi Publik}

Administrasi adalah organisasi dan manajemen dari setiap kerjasama untuk memperoleh sebuah sasaran yang telah ditentukan. (Kamaruddin Sellang, 2016). Administrasi publik berasal dari ilmu politik, yang ditujukan agar proses kegiatan kenegaraan dapat berjalan berdasarkan dengan sebuah sasaran yang ditetapkan (Suradinata dalam Anggara 2012). Administrasi publik juga sering dipandang sebagai suatu bagian yang memiliki kepentingan yang hampir sama dengan sebuah fungsi pelaksanaan kebijakan negara Para pakar e-ISSN 2716-165X menggunakan terminologi Public policy, bahkan dikenal dengan istilah lain yaitu kebijakan publik dan kebijaksanaan publik. Istilah kebijakan lebih mengarah pada suatu produk yang telah ditetapkan oleh badanbadan publik yang bermodelkan peraturan per- undang-undangan, sedangkan dalam kebijaksanaan lebih mengutamakan pada fleksibilitas dalam suatu kebijakan.

\section{Komunikasi Organisasi}

Komunikasi memiliki pengertian yang begitu sangat luas yakni, baik sebagai suatu ilmu yang tersendiri sebagai suatu proses. adapun indikator yang diperuntukan untuk mengukur suatu komunikasi dalam suatu organisasi menurut Fredric M Jabin dalam Zainuddin (2017: 375)

a. Bijaksana dan Kesopanan, yaitu cara berkomunikasi dengan memiliki suatu pilihan kata yang sangat tepat dan cara menyampaikan sesuatu harus menggunakan bahasa yang sopan dan halus.

b. Penerimaan Umpan Balik, yaitu penerimaan tanggapan dari pesan yang disampaikan. Menurut Suhadi(2008) yaitu suatu bagian penting dalam kegiatan di Kantor Kelurahan Arateng, umpan balik ini sangat mempengaruhi komunikasi organisasi dalam efektivitas kerja aparat di Kantor Kelurahan Arateng.

c. Berbagi informasi, yaitu meneruskan sebuah informasi baik informasi mengenai kemajuan maupun dengan suatu persoalan yang ada pada atasan dan bawahan.

d. Memberikan informasi tugas, yaitu memberitahukan sebuah informasi yang berkenaan dengan hal-hal yang bersangkutan dengan tugas. Menurut Siswanto (2002) yaitu Sebuah rincian pekerjaan yang berisikan informasi menyeluruh Mengenai tugas/kewajiban yang sudah di perintahkan oleh Atasan kepada bawahan di Kantor Kelurahan Arateng.

e. Mengurangi ketidak pastian tugas, yaitu menyampaikan suatu informasi yang memiliki kejelasan dan lengkap mengenai Waktu pelaksanaan sesuai dengan yang diharapkan.

Redding dan sanborn (2000:66) mengemukakan mengenai komunikasi organisasi yaitu suatu bentuk pemberian dan 
penerimaan suatu informasi bagi sebuah organisasi yang sangat kompleks. Arti sebuah komplek dalam hal ini adalah mencakup suatu hubungan yang terjalin antara manusia seperti hubungan pimpinan dan bawahan, penggunaan suatu sarana dalam menyampaikan sebuah pesan, keterampilan di dalam berkomunikasi antara sesama lapisan organisasi.

\section{Efektivitas Kerja}

Soewarno Handayaningrat dalam Zainuddin (2017:168) mengatakan bahwa efektivitas yaitu suatu pengukuran dalam arti tercapainya suatu sasaran yang telah ditetapkan sebelumnya. Sedangkan Hidayat dalam zainuddin (2017:168) yang merumuskan bahwa efekivitas adalah sebuah alat ukuran yang mengatakan bahwa seberapa jauh target (kuantitas, kualitas dan waktu) sudah tercapai, semakin besar hasil persentase bagi sasaran yang diperoleh, semakin tinggi efektifitasnya. Perspektif tersebut sejalan dengan padangan Mahmudi dalam Zainuddin (2017:168) mengemukakan definisi efektivitas yaitu suatu hubungan antara output dengan tujuan, semakin besar kontribusi bagi output terhadap tercapaianya tujuan, maka semakin efektif organisasi, Pada dimensi yang sama Sejathi dalam Zainuddin (2017:168) menyatakan definisi efektivitas yaitu ketepatgunaan, hasil guna, menunjang tujuan.

Berdasarkan pendapat yang dikemukakan para ahli dalam uraian diatas dapat kita menyimpulkan yakni efektivitas kerja yaitu suatu kegiatan yang dilaksanakan dengan sempurna , sehingga suatu pencapaian tujuan dalam suatu organisasi akan berjalan dengan sesuai yang sudah Tetapkan sebelumnya. Menurut Hasibuan (2003:105) Indikator yang digunakan bagi efektivitas kerja yakni :

a. Kuantitas Kerja

Kuantitas kerja yaitu volume kerja yang dicapaik dalam suatu kondisi normal. Hal ini dibuktikan dari banyaknya suatu tantangan kerja yang dihadapi selama kerja. Setiap organisasi akan berusaha supaya keefektifan dari seluruh pegawainya dapat meningkat. Oleh sebab itu, setiap suatu perusahaan akan memperjuangkan supaya pegawainya mepunyai moral kerja yang sanagt tinggi.

b. Kualitas Kerja
p-ISSN 2302-6960

e-ISSN 2716-165X

Kualitas kerja yaitu sikap yang ditonjolkan oleh setiap pegawai terhadap hasil kerja seperti kerapihan, ketelitian dengan tidak mengabaikan volume kerja dalam mengerjakan pekerjaan tersebut .

c. Pemanfaatan Waktu

Pemanfaatan waktu yaitu cara memaksimalkan waktu kerja yang telah ditentukandalam peraturan dengan kebijakan perusahaan supaya semua pekerjaan terselesaikan dengan tepat pada waktu berdasarkan peraturan yang sudah ditentukan.

\section{Faktor-Faktor yang Mempengaruhi Komunikasi Organisasi}

Gibson et al dalam Zainuddin (2017:

376) faktor-faktor tersebut meliputi :

a. Komunikasi Horizontal (Komunikasi Lateral) yaitu suatu bentuk dalam sebuah komunikasi secara mendatar dimana terjadinya suatu proses pertukaran pesan secara menyimpang yang dilaksanakn oleh dua pihak dan memiliki tingkatan yang sama dalam suatu organisasi

b. Komunikasi diagonal yaitu komunikasi yang akan berlangsung dari satu pihak kepada pihak lain dalam posisi yang berbeda, dimana kedua pihak tidak berada pada jalur struktur yang sama. Komunikasi diagonal bisa digunakan oleh dua pihak yang memilki tingakt yang berbeda tetapi tidak mempunyai wewenangyang secara langsung kepada pihak lain

c. Komunikasi vertikal yaitu komunikasi yang bisa terjadi antara atasan dan bawahan dalam sebuah organisasi. Robbins dalam Zainuddin (2017:377), mendefinisikan bahwa komunikasi vertikal yaitu suatu komunikasi yang mengalir dari satu tingkat dalam suatu organisasi bagi tingkat yang lebih tinggi atau tingkat yang rendah secara timbal balik. Dalam lingkungan organisasi, komunikasi bagi atasan dan bawahan menjadi salah satu kunci yang sangat penting dalam suatu kelangsungan hidup terhadap suatu organisasi.

\section{B. METODE PENELITIAN}

Penelitian ini menggunakan dua variabel yakni komunikasi organisasi sebagai variabel independen (bebas) dan efektivitas kerja aparat sebagai variabel dependen 
(terikat), sedangkan tipe penelitian deskriptif kuantitatif, untuk memberikan gambaran dengan cermat, jelas dan objektif maka metode ini diharapkan dapat memberikan gambaran secara cermat, jelas dan objektif mengenai masalah yang sedang diteliti.

Populasi dalam penelitian ini adalah seluruh aparat di Kelurahan Arateng, maka jumlah populasi dalam penelitian ini yaitu 32 orang. Kelurahan Arateng terdiri dari dua lingkungan yaitu lingkungan I Pallae dan lingkungan II Lasalama. Jika jumlah subjeknya besar dapat diambil antara 10$15 \%$ atau $20-25 \%$ atau lebih tergantung sedikit banyaknnya. Kemampuan penelitian dilitihan dari waktu, tenaga dan dana, Sempit luasnya wilayah pengematan dari setiap subyek, karena hal ini menyangkut banyak sedikitnya dana yang tersedia, besar kecilnya resiko yang ditanggung oleh peneliti untuk peneliti yang resikonya besar, tentusaja jika sampelnya besar hasilnya akan lebih baik. Maka pengambilan sampel ini dilakukan dengan mengambil seluruh jumlah populasi sebanyak 32 orang seluruh aparat Kelurahan Arateng.

Teknik Pengumpulan Data Dalam penelitian ini, digunakan beberapa teknik pengumpulan data, yang meliputi: Observasi, Penelitian pustaka, dan Kuesioner/Angket. Berdasarkan jenis data yang sudah terkumpul, maka dilakukan analisis dengan bantuan tabel frekuensi dan SPSS 19. Nilainilai varian sebagai hasil olahan data akan menggambarkan suatu hubungan antara variabel yang satu dengan variabel lainnya. Data hasil penelitian dianalisis dengan alat statistik yang terdiri dari: Analisis Deskriptif, Uji Kualitas Data (Validitas dan reabilitas), Uji Asumsi Klasik, Regresi Linear sederhana dan Pengujian Hipotesis.

\section{Hasil Penelitian dan Pembahasan}

Bijaksana dan kesopanan : pengaruh cara berkomunikasi yang sopan kepada aparatur $61.8 \%$. b. Penerimaan umpan balik $63 \%$. c. Berbagi informasi : pengaruh penyampaian dalam memberikan informasi baik itu laporan atau masalah kepada sesama aparatur $60 \%$. d. Memberikan informasi tugas : pengaruh pimpinan dalam memberikan informasi seperti tugas-tugas kantor kepada sesama aparatur $66.8 \%$. e. Mengurangi ketidakpastian tugas : pengaruh penyampaian informasi yang jelas dan lengkap kepada sesama aparatur dalam lingkungan $61.8 \%$.

Hasil penelitian efektivitas kerja $(\mathrm{Y})$ : a. Kuantitas kerja : pengaruh volume kerja yang dihasilkan aparatur $61.8 \%$. b. Kualitas kerja : pengaruh sikap yan ditunjukkan oleh aparatur $62.4 \%$. c. Pemanfaatan waktu : tentang pengaruh pengunaan masa kerja yang disesuaikan $60 \%$. faktor-faktor yang mempengaruhi komunikasi organisasi : a. Komunikasi horizontal : pengaruh pertukaran pesan yang dilakukan oleh aparat $62.4 \%$. b. Komunikasi diagonal : pengaruh komunikasi antara aparat yang memiliki posisi yang berbeda 56.2 \%.c komunikasi vertikal : pengaruh komunikasi yang terjadi antara pimpinan dan bawahan $56.2 \%$.

Sesuai hasil olah data, diketahui memiliki lima item pertanyaan yang dipakai untuk mengukur variabel komunikasi organisasi $(X)$ dinyatakan valid dengan nilai corrected item-total correlation> $0.25,0.30$ (corrected item-total correlation> $0.25,0.30$ ) yaitu X1: 0.410, X2:0.410, X3:305, X4:0.475, $X 5: 609$. Berdasarkan table 4.31 hasil olah data di atas, diketahui bahwa 3 item pertanyaan yang digunakan untuk mengukur variabel (efektivitas kerja) dinyatakan valid dengan nilai corrected item-total correlation lebih besar dari $>0.25,0.30$ (corrected itemtotal correlation $>0.25,0.30$ ) yaitu $\mathrm{Y} 1: 410$, Y2:523, Y3: 464. Berdasarkan table 4.33 hasil olahan data tersebut, diketahui bahwa 3 item pertanyaan yang digunakan untuk mengukur variabel (factor-faktor yang mempengaruhi komunikasi organisasi) dinyatakan valid dengan nilai corrected itemtotal correlation lebih besar dari $>0.25,0.30$ (corrected item-total correlation> $0.25,0.30$ ) yaitu F1:0.659, F2:0.634, F3:0.642.

Reliability statistics penelitian yang digunakan untuk mengukur variabel $X$ reliabel atau hAparaturl karena Cronbach Alpha yang diperoleh adalah sebesar 0.685 yang berarti lebih besar dari 0.60 (0.685 > 0.60). Berdasarkan reliability statistics, kuesioner penelitian yang digunakan untuk mengukur variabel $\mathrm{Y}$ reliabel atau hAparaturl karena Cronbach Alphayang diperoleh adalah sebesar 0.648 yang berarti lebih besar dari $0.60(0.648>0.60)$. Reliability statistics, kuesioner penelitian yang digunakan untuk mengukur variabel $F$ reliabel atau hAparaturl karena Cronbach Alphayang diperoleh adalah sebesar 0.800 yang berarti lebih besar dari 0.60 (0.800 > 
0.60). Berdasarkan dari uji normalitas dengan Kolmogorov-Smirnov Test yang telah dilakukan maka diperoleh KSZ dengan nilai sebesar 0.626 dan Asymp. Sig. (2-tailed) 0.828 . Lebih besar dari 0,05 , maka dapat disimpulkan bahwa data tersebut berdistribusi normal.

Hasil uji Model Summary, pada bagian ini ditampilkan ni $\mathrm{R}=0.408$ dan koefisien Determination Rsquare atau $\left(R^{2}\right)$ nilai sebesar 0.167 (hasil dari pengkuadratan koefisienkorelasi atau (R) $0.408 \times 0.408=$ $0.167 \times 100 \%=16.7 \%)$, sedangkan sisanya $(100 \%-16.7 \%=83.3 \%)$. Hal ini menunjukkan bahwa untuk mencari besar faktor komunikasi organisasi (X) terhadap efektivitas kerja $(\mathrm{Y})$ dengan ini nilai yang dicari yaitu $16.7 \%$.

Hasil dari uji ANOVA pada bagian ini ditampilkan hasil yang diperoleh adalah nilai $\mathrm{F}=6.007$ dengan tingkat probabilitas sig. 0.000 . Oleh karena probabilitas $(0,000)$ jauh lebih kecil dari 0.05 , maka model regresi bisa dipakai untuk memprediksi komunikasi organisasi. Untuk menguji kebenaran hipotesis dalam penelitian ini dilakukan uji $F$. Untuk mengetahui bahwa pengaruh / Signifikan dapat diketahui dengan melihat dari lefel of signifikan a $=0,05$. Jika nilai signifikan lebih kecil dari 0,05 , maka $\mathrm{HO}$ ditolak dan Ha diterima

Berdasarkan hasil olah data pada tabel ANOVA maka diketahui nilai Fhitung yang diperoleh sebesar 6.007 dengan tingkat signifikan 0,000 (Sig < 0,05) yang berarti bahwa variabel komunikasi organisasi $(X)$ mempunyai pengaruh/signifikan terhadap efektivitas kerja (Y), dari hasil tersebut berarti model regresi dapat digunakan untuk memprediksi efektivitas kerja di Kantor Kelurahan Arateng Kecamatan Tellu Limpoe Kabupaten Sidenreng Rappang.

Berdasarkan Coefficients hasil olah data, maka model regresi yang digunakan dalam penelitian ini untuk mengukur pengaruh komunikasi organisasi terhadap efektifitas kerja aparat di Kantor Kelurahan Arateng Kecamatan Tellu Limpoe Kabupaten Sidenreng Rappang.

$$
Y=2.330+0.432 X
$$

Dari fungsi regresi di atas, maka dapat dijelaskan :

1. Jika variabel Komunikasi Organisasi $(X)$ berubah, maka efektivitas kerja $(Y)$ juga akan berubah. Tanda positif menunjukkan perubahan yang searah.
p-ISSN 2302-6960

e-ISSN 2716-165X

Apabila

Komunikasi

Organisasimeningkat, maka efektivitas kerja juga akan meningkat dengan koefisien regresi sebesar 0. 432 dan sebaliknya, jika komunikasi organisasi menurun, maka efektivitas kerja juga akan menurun dengan koefisien regresi sebesar.

2. Nilai konstanta sebesar 2.330 menunjukkan bahwa, jika semua variabel konstan maka Model komunikasi organisasi bersifat positif.

Uji statistic $t$ untuk menunjukkan seberapa jauh pengaruh satu variabel penjelas/independen secara individual menerangkan variasi variabel dependen berdasarkan tabel coefficients hasil olah data SPSS, maka diketahui bahwa :

a. Nilai thitungvariabel komunikasi organisasi (X) 2.451 dengan tingkat signifikan 0,000 .

b. Hipotesis berdasarkan uji $t$ dirumuskan secara statistic

$\mathrm{Ha}:$ Pyx $\neq 0$

$\mathrm{HO}:$ Pyx $\neq 0$

Hipotesis bentuk kalimat:

1. $\mathrm{Ha}:$ komunikasi organisasi berpengaruh/signifikan terhadap efektivitas kerja aparat di Kantor Kelurahan Arateng Kecamatan Tellu Limpoe Kabupaten Sidenreng Rappang.

2. HO : komunikasi organisasi tidak berpengaruh/signifikan terhadap efektivitas kerja aparat di Kantor Kelurahan Arateng Kecamatan Tellu Limpoe Kabupaten Sidenreng Rappang

Pengambilan Keputusan :

1. Jika nilai $\mathrm{t}$ hitung $\geq \mathrm{t}$ tabel, maka $\mathrm{HO}$ ditolak dan $\mathrm{Ha}$ diterima, artinya Signifikan.

2. Jika nilai $\mathrm{t}$ hitung $\leq \mathrm{t}$ tabel, maka $\mathrm{HO}$ diterima dan $\mathrm{Ha}$ ditolak, artinya tidak Signifikan.

Tabel Coefficients diperoleh $\mathrm{t}$ hitung $=$ 2.451 prosedur mencari statistic tabel dengan kriteria

1. Tingkat signifikan $(a=0,05)$

2. $\mathrm{df}=$ Jumlah Responden -2 atau $32-2=30$

3. $\mathrm{t}$ tabel $=\mathrm{a} / 2 ; \mathrm{df}$

$$
\begin{aligned}
& =0,05 / 2 ; \mathrm{df} \\
& =0,025 ; 30
\end{aligned}
$$

Sehingga $\mathrm{t}$ tabel $=0.349$

Keputusan : 
Ternyata nilai $\mathrm{t}$ hitung $>\mathrm{t}$ tabel atau $2.451>0.349$, maka $\mathrm{HO}$ ditolak dan $\mathrm{Ha}$ diterima, artinya signifikan. Jadi, komunikasi organisasi berpengaruh signifikan terhadap efektivitas kerja aparat di Kantor Kelurahan Arateng Kecamatan Tellu Limpoe Kabupaten Sidenreng Rappang.

Sesuai dengan hasil penelitian yang telah dipaparkan sebelumnya. Penulis akan membahas hasil pene;itian sesuai dengan konsep pengukuran komunikasi organisasi meliputi bijaksana dan kesopanan, penerimaan umpan balik, berbagi informasi, mengurangi ketidak pastian tugas. Kemudian konseo pengukuran efektivitas kerja meliputi kuantitas keja, kualitas kerja dan ketepatan waktu Pengaruh komunikasi organisasi terhadap efektivitas kerja aparat di kantor kelurahan arateng kecamatan tellu limpoe kabupaten sidenreng rappang.

1. Bijaksana dan Kesopanan yaitu komunikasi dengan menggunakan pilihan kata yang tepat dan disampaikan dengan bahasa yang sopan dan halus. Bijaksana adalah sikap tepat dalam menyikapi setiap keadaan dan peristiwa sehingga memancarlah keadilan. Sedangkan kesopanan adalah peraturan sosial yang mengarah ke hal-hal berkenaan dengan cara seseorang bertingkah laku wajar dalam kehidupan dalam masyarakat. Bijaksana dan kesopanan yang dimaksud disini adalah cara berkomunikasi yang sopan kepada aparatur dengan presentase sebesar $61.8 \%$.

2. Penerimaan umpan balik ( feedback) yaitu tanggapan yang dibeikan oleh seseorang komunikasi (penerima pesan) ketika seseorang komunikato (pemberi pesan ) sedang menyampaikan pesannya. Dalam artian singkat, feedback dapat dikatakan sebagai tanggapan atau respon terhadap suatu pesan. Feedback yang ditimbulkan dari proses komunikasi memberikan gambaran kepada komunkator tentang hasil komunikasi yang dilakukan. Indikator ini sangat penting dalam kegiatan di kantor. Penerimaan umpan balik yang dimaksud disini adalah pengaruhpenyampaian dalam menyampaikan pesan atau informasi kepada aparatur dengan presentase sebesar $63 \%$.

3. Berbagi Informasi yaitu memberikan informasi, baik informasi kemajuan maupun permasalahan yang ada kepada
p-ISSN 2302-6960

e-ISSN 2716-165X

rekan sekerja maupun pimpinan. sedangkan informasi dapat diartikan suatu data yang telah diproses dan diubah menjadi konteks yang berarti sehingga memilki makna dan nilai bagi penerimanya dan bias digunakan untuk pengambilan keputusan. berbagai informasi yang dimaksud disini adalah penyampaian dalam memberikan informasi baik itu laporan atau masalah kepada sesama aparatur dengan persentase sebesar $60 \%$.

4. Memberikan Informasi Tugas menyampaikan informasi mengenai halhal yang berkaitan tugas. Memberikan hasil pengolahan data yang memilki arti manfaat bagi surat, pesanan, faktur, panggilan telepon dan semua informasi yang masuk untuk memperoleh nantinya informasi yang akan diberikan. Memberikan informasi tugas yang dimaksud disini adalah pengaruhpimpinandalammemberikan

informasi seperti tugas-tugas kantor kepada sesama aparatur dengan persentase sebesar $66.8 \%$.

5. Mengurangi Ketidakpastian Tugas menyampaikan informasi yang jelas dan lengkap dengan mengenai pelaksanaan dapat diselesaikan sesuai yang diharapkan. Menyampaikan faktor-faktor penyebab terjadinya ketidakpuasan dan mengkondisikan dirinya untuk memandang bekerja itu adaalah ibada . mempelajari dan mengambil teladan yang baik meningkatkan relasi sosial horizontal dan vertical ditempat kerjanya, meningkatkan pengetahuan dan keterampilan, menyesuaikan diri dengan lingkungan kerj. Mengurangi ketidakpastian tugas yang dimaksud disini adalah pengaruhpenyampaian informasi yang jelas dan lengkap kepada sesama aparatur dengan persentase sebesar $61.8 \%$.

Soewarno Handayaningrat dalam Zainuddin (2017:168) mengatakan bahwa efektivitas yaitu suatu pengukuran dalam arti tercapainya suatu sasaran yang telah ditetapkan sebelumnya

1. Kuantitas kerja yaitu volume kerja yang dihasilkan dibawah kondisi normal. Maka dapat dilihat dari banyaknya beban kerja dan keadaan yang didapat atau dialaminya selama kerja. Setiap kantor akan selalu berusaha agar efektivitas dari 
pegawainya dapat ditingkatkan dan berusaha juga agar pegawainya memilki moral kerja yang tinggi. Kuantitas kerja yang dimaksud disini adalah volume kerja yang dihasilkan aparatur dengan persentase sebesar $61.8 \%$.

2. Kualitas Kerja yaitu sikapyang ditunjukkan oleh pegawainya berupa hasil kerja dalam bentuk kerapihan, ketelitian dan keterkaitan hasil dengan tidak mengabaikan volume pekerjaan didalam mengerjakan pekerjaan. Kuantitas kerja yang dimaksud disini adalah sikap yan ditunjukkan oleh aparatur dengan persentase sebesar $62.4 \%$.

3. Pemanfaatan Waktu yaitu penggunaan masa kerja yang disesuaikan dengan kebijakan perusahaan agar pekerjaan selesai tepat waktu yang telah ditetapkan atau yang sudah ditentukan. Pemanfaatan waktu yang dimaksud disini adalah pengunaan masa kerja yang disesuaikan terhadap efektivitas kerja aparatur dengan persentase sebesar $60 \%$.

Gibson et al dalam Zainuddin (2017:

376) faktor-faktor tersebut meliputi

1. Komunikasi Horizontal yaitu bentuk komunikasi secara mendatar dimana terjadi pertukaran pesan secara menyimpang dan dilakukan oleh dua pihak yang mempunyai kedudukan yang sama, jabatan yang se-level maupun eselon yang sama dalam suatu organisasi. Bentuk komunikasi seperti ini selain berguna untuk menginformasikan juga untuk meminta dukungan dan mengkoordinasikan aktivitas. Komunikasi horizontal yang dimaksud disini adalah pertukaran pesan yang dilakukan oleh aparat dengan persentase sebesar 62.4 $\%$.

2. Komunikasi Diagonal yaitu komunikasi yang berlangsung dari satu pihak kepada pihak lain dalam posisi yang berbeda, dimana kedua pihak tidak berada pada jalur struktur yang sama. Bentuk komunikasi ini sangat jarang digunakan dalam organisasi, namun sangat penting dalam situasi dimana anggota tidak dapat berkomunikasi secara efektif . komunikasi diagonal yang dimaksud disini adalah komunikasi antara aparat yang memiliki posisi yang berbeda dengan persentase sebesar $56.2 \%$.
3. Komunikasi Vertikal yaitu komunikasi yang terjadi antara atasan dan bawahan dalam organisasi. Dalam lingkungan organisasi, komukasi ini merupakan kunci penting dalam kelangsungan hidup suatu organisasi. Komunikasi vertikal yang dimaksud disini adalah dengan persentase sebesar $56.2 \%$.

\section{KESIMPULAN}

Berdasarkan dengan hasil penelitian dan pembahasan dapat ditarik kesimpulan sebagai berikut :

1. Hasil penelitian dari Komunikasi Organisasi (X) : a. Bijaksana dan kesopanan : pengaruh cara berkomunikasi yang sopan kepada aparatur $61.8 \%$. b. Penerimaan umpan balik 63 \%. c. Berbagi informasi : pengaruhpenyampaian dalam memberikan informasi baik itu laporan atau masalah kepada sesama aparatur $60 \%$. d. Memberikan informasi tugas : pengaruhpimpinandalam memberikan informasi seperti tugas-tugas kantor kepada sesama aparatur $66.8 \%$. e. Mengurangi ketidakpastian tugas : pengaruh penyampaian informasi yang jelas dan lengkap kepada sesama aparatur dalam lingkungan $61.8 \%$. Hasil penelitian dari efektivitas kerja (Y) : a. Kuantitas kerja : pengaruh volume kerja yang dihasilkan aparatur $61.8 \%$. b. Kualitas kerja : pengaruh sikap yan ditunjukkan oleh aparatur $62.4 \%$. c. Pemanfaatan waktu : tentangpengaruh pengunaan masa kerja yang disesuaikan $60 \%$.Berdasarkan hasil perhitungan SPSS versi 21 maka, t hitung > t tabel atau $2.451>0,349$, maka $\mathrm{HO}$ ditolak dan $\mathrm{Ha}$ diterima, artinya signifikan. Jadi, komunikasi organisasi berpengaruh signifikan terhadap efektivitas kerja aparat di Kantor Kelurahan Arateng Kecamatan Tellu Limpoe Kabupaten Sidenreng Rappang.

2. Hasil penelitian dari faktor-faktor yang mempengaruhi komunikasi organisasi : a. Komunikasi horizontal : pengaruh pertukaran pesan yang dilakukan oleh aparat $62.4 \%$. b. Komunikasi diagonal : pengaruh komunikasi antara aparat yang memiliki posisi yang berbeda $56.2 \%$. C. komunikasi vertikal : pengaruh komunikasi yang terjadi antara pimpinan dan bawahan $56.2 \%$. 


\section{E. DAFTAR PUSTAKA}

Ahmad, jamaluddin.2015. Metode Penelitian Administrasi Publik Teori dan Aplikasinya. Gave Media. Yogjakarta .

Anggara, S. (2012). perbandingan administrasi negara.

Zainuddin. 2017. Teori-Teori Mutakhir Dalam Perspektif Ilmu Administrasi Publik. Makassar : Phinatama Media ( Phinisi Utama Media)

Handoko Martin, 2006. Motivasi Daya Penggerak Tingkah Laku, Jakarta : Kanisius.

Moeheriono.2009. Pengukuran Kinerja Berbasis Kompetensi. Jakarta: Ghalia Indonesia.

Robbins. Stepen. P. 2001. Perilaku Organisasi . Edisi Ke 10, PT. Indeks. Jakarta

Sartika, D. (2014). PENGARUH KOMUNIKASI ORGANISASI TERHADAP EFEKTIVITAS KERJA PEGAWAI PADA SEKRETARIAT DAERAH KABUPATEN PINRANG Skripsi.

Sugiyono (2011). Metode Penelitian Pendidikan (Pendekatan Kuantitatif, Kualitatif, Dan R\&D). Bandung: Alfabeta.

Suprihati, 2014. Analisis Faktor-Faktor Yang Mempengaruhi Kinerja Karyawan Perusahaan Sari Jati Di Sragen. STIE AAS SUKARTA.

\section{Dokumen :}

Undang-Undang Nomor 5 Tahun 2014 tentang ASN (Aparatur Sipil Negara). 